\title{
Anmeldelse: Bent Jensens lukkede bog
}

\author{
Af Ib Faurby
}

Bent Jensens mammutværk "Ulve, får og vogtere" om den kolde krig skaber ikke større klarhed om Danmark under den kolde krig - snarere tværtimod

Det helt dominerende tema i Bent Jensens to-binds værk er, hvordan Sovjetunionen gennem et systematisk og vedvarende pres via den danske venstrefløj og især Socialdemokratiet skadede Danmarks sikkerhed ikke mindst ved at undergrave medlemskabet af NATO. Denne tolkning af dansk sikkerhedspolitik lancerede BJ allerede i 1987 med bogen Tryk og tilpasning. Sovjetunionen og Danmark siden 2. verdenskrig.

Den nye næsten seks gange længere fremstilling har til formål at underbygge denne tese med et overvældende antal referater og citater fra sovjetiske kilder, rapporter fra PET og FE, dokumenter fra Udenrigsministeriet, mere eller mindre obskure venstrefløjspublikationer samt danske socialdemokraters - ikke mindst Lasse Budtz' og Anker Jørgensens - udtalelser og handlinger. Trods det nye værks omfang føjer det ikke afgørende nyt til den oprindelige tolkning i Tryk og tilpasning.

Ligesom BJ's tidligere bøger bl.a. Bjørnen og haren. Sovjetunionen og Danmark 1945-1965 (1999) er Ulve, får og vogtere et vidnesbyrd om forfatterens store flid. At han også er en polemiker for Herren, ved de fleste avislæsere. Det sætter også sit umiskendelige præg på hans seneste værk.

Værket har sin baggrund i to forhold: For det første i DIIS-rapporten Danmark unde den kolde krig, bind 1-4 (2005), som en del fandt utilstrækkelig eller direkte misvisende i sin undervurdering af den sovjetiske trussel og de negative virkninger af 'fodnotepolitikken' i 1980'erne. For det andet i Fogh Rasmussen-regeringens og Dansk Folkepartis ønske om et opgør med 'de kræfter i Danmark', der under den kolde krig med statsministerens ord 'reelt gik fjendens, altså Sovjetunionens og Warszawapagtens, ærinde’.

\section{Ulve, får og vogtere}

Til forståelse af værkets titel og kapiteloverskrifter blot denne ordforklaring: Ud over ulve og får optræder også andre dy-

Ib Faurby er tidligere lektor i international politik på Institut for Statskundskab ved Aarhus பniversitet. Han har desuden været sekretariatschef for Det Sikkerheds- og Nedrustningspolitiske Udvalg og medlem af dets formandskab. Han var været skribent på Politiken og derefter chefkonsulent ved Forsvarsakademiet og leder af Forsvarschefens Sikkerhedspolitiske Kursus. 
For de, der ikke selv oplevede den kolde krig, må mange af citaterne i Ulve, får og vogtereforekomme direkte absurde; for os andre vækker de minder om en tid, der heldigvis er forbi...
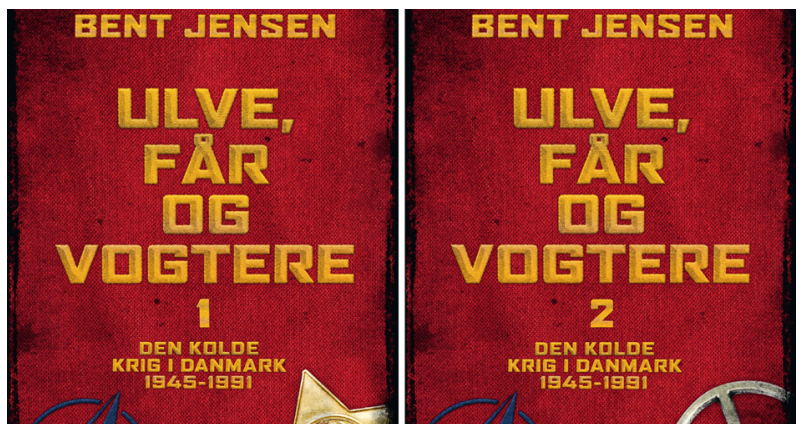

FOTO: [] GYLDENDAL rearter og dyr i forklædning. Der er 'haren' (Danmark), 'bjørnen' (Sovjetunionen), 'ulve i bjørnepels' (DKP), 'får i ulveklæder' (SF) og 'løven, der blev til lam' (Socialdemokratiet). Og så er der naturligvis vogterne, der måske burde hedde 'dyrepasserne' i den jensenske zoologiske have!

Første bind drejer sig om Sovjetunionen og den sovjetiske trussels karakter, den danske venstrefløjs (DKP, SF, VS og fredsbevægelsernes) følgagtighed, kulturkampen i Danmark under den kolde krig, spionage, sabotage og hvervning, såkaldte KGB- og STASI-nære danskere samt sovjetisk propaganda og KGB's påvirkningsoperationer.

Fremstillingen efterlader ingen tvivl om Sovjetunionens vedvarende politiske pres på Danmark eller den truende sovjetiske militære opbygning, men om værket dermed også opfylder de krav, kritikerne af DIIS-rapporten havde om en egentlig militær analyse, er tvivlsomt. For nogle måske, for andre ikke. BJ synes ikke for alvor at interessere sig for konkrete militære forhold, herunder den vestlige forskning vedrørende Warszawapagtens detaljerede krigsplanlægning, som vi i dag har kendskab til. At generaloberst Matvej Burlakov ikke, som hævdet i billedteksten side [1] 80, var chef for 'Den Sydlige Styrkegruppe' [sic!], hører dog til i småtingsafdelingen.

I andet bind beskrives (i velkendte for- mer) Danmarks utilstrækkelige forsvar, Sovjetunionens syn på Danmarks rolle i NATO, den danske ikke-provokationspolitik, femtekolonneloven og vogterne (PET, FE, det civile beredskab og regeringens sikkerhedsorganisation). Blandt vogterne finder man også ikke- eller antikommunistiske organisationer. Der er tillige et kapitel om kultureliten (de 'kulturradikale') og folket med den sunde skepsis over for de venstreorienterede. Værkets hovedemne - Socialdemokratiets 'forvandling', Sovjetunionens syn herpå og konsekvenserne for dansk udenrigs- og sikkerhedspolitik - behandles i tre kapitler, efterfulgt af en konklusion.

Blandt vogterene finder vi også en række enkeltpersoner og organisationer, der omkring krigsafslutningen og i de første efterkrigsår arbejdede for en klar dansk vestorientering. Her har BJ dog ikke inddraget Bo Lidegaards disputats I kongens navn (1996), hvis hovedemne er Henrik Kaufmanns tilsvarende bestræbelser. (Disputatsen er blot medtaget i en litteraturoversigt på Gyldendals hjemmeside). Det Udenrigspolitiske Selskabs og Atlantsammenslutningens formål og aktiviteter beskrives, men følges desværre ikke op til og med 'fodnoteperioden'.

Et andet bemærkelsesværdigt element er, at en række udenrigsministerielle embedsmænd, som BJ i tidligere publikationer har 
kritiseret og betegnet som 'neutralistiske', nu er blevet ophøjet til vogtere. Er det fordi, forfatteren i det nye værk har brug for 'helte', der kan skabe kontrast til 'skurkene' på venstrefløjen og i Socialdemokratiet?

\section{Venstrefløjen}

BJ har ligesom i bogen Stalinismens fascination og danske venstreintellektuelle (1984 og 2002) et godt øje for venstrefløjens naivitet eller fornægtelse af sovjetkommunismens karakter og (for nogles vedkommende) direkte støtte til Sovjetunionens sikkerhedspolitiske mål. For de, der ikke selv oplevede den kolde krig, må mange af citaterne i Ulve, får og vogtere forekomme direkte absurde; for os andre vækker de minder om en tid, der heldigvis er forbi, selvom der stadig er kold krig mellem historikere og anmeldere.

BJ skriver et par gange, at det er en ærlig sag at være uenig i regeringens politik. Det virker nærmest som en besværgelse, for synspunktet præger ikke den øvrige tekst. I en række personbeskrivelser fastholder han ikke en klar forskel mellem at være i politisk opposition, at være 'indflydelsesagent' eller være direkte i Sovjetunionens sold. Dertil kommer, at han er antydningernes mester.

Citatsamlingem er overvældende; intet synes for småt til at blive medtaget, når venstrefløjen skal hænges ud. Den uskønne blanding af relevante og selektivt udvalgte citater kaster et mistænkeligt skær - fortjent såvel som ufortjent - over adskillige personer. Har man fx for mere end 40 år siden udtalt sig kritisk eller direkte afstandtagende fra den amerikanske krigsførelse i Vietnam, så kan det (sammen med andet) bruges til en stigmatisering af den pågældende. Det rammer ikke bare Mogens Lykketoft, men også andre, $\mathrm{fx}$ en tidligere generalmajor, der $\mathrm{i}$ anden sammenhæng citeres for fodnotepolitikkens skadelige virkninger (side [2] 424426 og 521). Men at have været kritiker af den amerikanske krigsførelse i Vietnam var og er ikke nødvendigvis det samme som at være 'antiamerikansk' og peger ikke nødvendigvis frem mod en afstandtagen fra dansk NATO-medlemskab.

Med det jensenske perspektiv på nyere dansk historie har bevillingsgiverne utvivlsomt fåt den bog, de ønskede, en fremstilling, der 'skiller fårene fra bukkene'. Men hvor længe skal det blive ved med at være et centralt tema i dansk historieskrivning? BJ viser ingen nåde over for 'synderne'. Og nu, hvor NATO endnu engang har fået en generalsekretær, der i sin ungdom var 'fredsaktivist', kunne man (inspireret af BJ's bibelske terminologi) sige, at der tilsyneladende er mere glæde i NATO over én omvendt synder end 99 retfærdige - men ikke i Danmark.

BJ's udvælgelse og anvendelse af kilderne er, som påpeget af flere historikere, ofte problematisk. Eksemplerne er legio, så her skal blot tilføjes endnu ét. Det finder man (side [2] 446) i en enkelt sætning om den unge Jens Otto Krags første besøg i Sovjetunionen i 1946. På vejen hjem skrev han i sin dagbog: "Dette land skal man vise respekt".

Hvad Krag mente med den sætning, er ikke klart. Et gæt kunne være, at han ligesom mange andre fra hele det politiske spektrum havde respekt for Sovjetunionens indsats under den netop afsluttede krig og de enorme menneskelige og materielle ofre, krigen havde påført den sovjetiske befolkning. Den øvrige, levende 36 sider lange beskrivelse af besøget i bogen Travl tid, god tid (1974) er stærkt kritiske over for den politiske og sociale situation $\mathrm{i}$ Sovjetunionen (bortset fra en naiv vurdering af Krags kvindelige guide). Krag sammenligner således sovjetkommunismen med nazismen og Stalin med Hitler. Så hvad er hensigten med det løsrevne citat?

Bogens undertitel er 'Den Kolde Krig i Danmark 1945-1991'. Ordene 'i Danmark' er afgørende. Det er ikke en generel frem- 
stilling af den kolde krig, hvad BJ da heller ikke påstår. Men selvom fokus er på Danmark, så burde fremstillingen have været sat langt mere direkte og systematisk i relation til centrale sider af udviklingen under den kolde krig. Ofte får man som læser indtryk af, at det hele foregår i et lukket rum bestående af den sovjetiske partiledelse, den amerikanske regering og den danske venstrefløj. Dette rum har kun få og små vinduer til resten af verden, fx Europa.

Fremstillingen er fuldstændig sort/hvid. Bogens grundholdningen er, at alt, hvad den til enhver tid siddende amerikanske regering gjorde, var godt, rigtigt og tjente fredens sag. Her er ingen plads til nuancer endsige andre opfattelser. Nok var USA alliancens største og på mange måder mest afgørende land, men de enkelte vesteuropæiske lande havde på grund af geografi, historie og økonomi ikke nødvendigvis altid sammenfaldende interesser med USA. Gennem hele den kolde krig foregik der en løbende debat om politik og strategi over for Østblokken. Balancen mellem national interessevaretagelse og alliancesolidaritet kunne variere afhængigt af det aktuelle spændingsniveau i forholdet mellem Øst og Vest.

\section{Ahistorisk fremstilling}

Et gennemgående tema var balancen mellem afskrækkelse og afspænding. Det kom bl.a. til udtryk i Harmel-rapporten fra 1967. Det var et tema, der - uafhængigt af partipolitiske holdninger i øvrigt også var centralt i dansk alliancepolitik. Men det er underspillet i BJ's fremstilling, og Harmel-rapporten er overhovedet ikke nævnt. Hverken Helsinki-processen eller Vesttysklands østpolitik får en relevant behandling, selvom begge var centrale for den sikkerhedspolitiske udvikling i Europa. Det får fremstillingen til at virker næsten ahistorisk.

Heller ikke forskelle mellem USA's og de europæiske NATO-landes opfattelser af NATOs militære strategi synes at interesse- re forfatteren. USA var og er en supermagt med globale interesser og hovedansvar for den nukleare afskrækkelse. Storbritannien og Frankrig var og er stormagter med egne kernevåben og har dermed et andet syn på visse strategiske spørgsmål. Vesttyskland havde særlig interesse i forhold til borgerne i DDR og frygt for, at det centrale Europa skulle blive krigsskueplads, konventionel såvel som nuklear.

Tilsvarende havde de øvrige NATO-medlemmer deres interesser. Det interessante er, hvordan sådanne interesseforskelle blev afvejet i forhold til den fælles alliancestrategi - en afvejning der prægede alliancen i alle årene. Det var ikke tilfældigt, at det tog fem år, før NATO tilsluttede sig USA's strategiskifte fra 'massiv gengældelse' til 'det fleksible svar'. Man kunne også se disse interesseforskelle i debatten om den multilaterale kernevåbenudrustede flådestyrke (MLF), der ikke blev til noget, og i striden i 197778 om den såkaldte neutronbombe, der var et forvarsel om de vanskeligheder, dobbeltbeslutningen løb ind $\mathrm{i}$.

BJ omtaler det strategiske hovedargument for opstilling af kernevåbenudrustede Pershing II- og krydsermissiler i Vesteuropa (koblingen til de amerikanske strategiske våben) og det politisk mere enkle argument (afbalancering af de sovjetiske SS 20-missiler). Han omtaler også hovedproblemerne forbundet med en isoleret eller ensidig kernevåbenfri zone i Norden. Men egentlig synes BJ ikke at have den store interesse for kernevåbenstrategiske spørgsmål. Hans holdning til kernevåben i almindelighed og rustningskontrol i særdeleshed forekommer næsten nonchalant.

Et eksempel finder man i omtalen af SDI (Præsident Reagans strategiske forsvarsinitiativ, populært kendt som 'stjernekrigsprojektet'). BJ skriver stort set intet om selve projektet. Og slet intet om den betydelige debat blandt såvel fysikere som strategiske analytikere i USA og flere vesteuropæiske lande om projektets re- 
alisme og dets strategiske konsekvenser, hvis det lod sig realisere. Hvad ville det betyde fx for ABM-traktaten og den strategiske stabilitet? ABM-traktaten omtales i øvrigt kun én gang (side [1] 70-71) og det blot i tre sætninger, der ser den som en ren foræring til Sovjetunionen.

BJ's behandling af SDI-spørgsmålet drejer sig kun om den anden af de to dagsordner om sagen, Folketinget vedtog (side [2] 402-404). Og han har da ret i, at det var tåbeligt eller i bedste fald enfoldigt at vedtage en dagsorden, der opfordrede til et generelt forbud mod forskning i missilforsvarsvåben - ikke et dansk 'nej, tak', men et globalt forbud.

Perspektivet er snævert dansk. Det er socialdemokraterne og den egentlige venstrefløj i Danmark, der førte en uansvarlig politik på grund af Sovjetunionens militære tryk og undergravende virksomhed. Det nævnes naturligvis, at også andre europæiske socialdemokratier og venstreorienterede partier havde tilsvarende standspunker, og at de arbejdede sammen og gensidigt inspirerede hinanden bl.a. gennem samarbejdet i Socialistisk Internationale og Scandilux. Men en egentlig sammenlignende analyse af situationen i Danmark med de øvrige Scandilux-lande mangler.

Det samme gælder, som nævnt, den bredere politiske og strategiske debat i alliancens medlemslande. Denne debat var velkendt af nogle få embedsmænd og officerer samt enkelte forskere. Den blev også udnyttet af de mest velinformerede kritikere på den danske venstrefløj i deres argumentation. Men dette aspekt er stort set fraværende i bogen. Et af de få steder, hvor BJ strejfer den amerikanske debat, er i en bemærkning om, at Jørgen Dragsdahl og andre byggede på materiale fra "det antiamerikanske og prokommunistiske nedrustningsmiljø i USA" (side [1] 50). Mere relevant bliver synspunktet ikke af en næsten ordret gentagelse i bind 2. Det er ganske enkelt for letkøbt!
Det illustrerer, at selv blandt helhjertede danske alliancetilhængere var interessen for og viden om disse forhold såre begrænset. Og netop det blev et problem i den politiske debat i 1980'erne. Venstrefløjens kritik af NATOs strategi blev som oftest af borgerlige politikere og debattører ikke mødt med argumenter, men med almindeligheder og ideologiske erklæringer.

Selv når den internationale debat om kernevåbenpolitiske og -strategiske problemer lejlighedsvis fandt sted i Danmark med deltagelse af udenlandske og danske forskere samt danske embedsmænd og officerer og kritiske repræsentanter fra venstrefløjen, ikke at forglemme! - interesserer det ikke BJ. End ikke den bog, der blev resultatet af en sådan konference om INF-sagen, der fandt sted i regi af Det Sikkerheds- og Nedrustningspolitiske Udvalg, som BJ selv var medlem af, er fundet værdig til omtale, selvom den optræder på litteraturlisten. I rapporten fra en tilsvarende konference om Danmark og NATOs strategi arrangeret af Det Krigsvidenskabelige Selskab har BJ blot fundet et par løsrevne citater fra de deltagende NATO-kritikere.

\section{Problematiske udeladelser}

Værket er heller ikke en udtømmende behandling af dansk politik under den Kolde Krig. I den første note til kapitel 20 hedder det: "Dette kapitel behandler ikke generelt den parlamentariske situation eller regeringens politik, men koncentrerer sig om Socialdemokratiets og dets alternative flertal i 1980'erne". Men det er ikke kun dette kapitel. Intet sted i det 1.500 sider store værk finder man en egentlig analyse af regeringens politik, den parlamentariske situation og det politiske spil om sikkerhedspolitikken.

Den måske mest overraskende udeladelse i denne bog, hvis erklærede formål er at vise, at: "Fodnotepolitikken var et hasarderet spil med Danmarks sikkerhed, der blev bragt i alvorlig fare. . " (side [2] 594) er, 
at der mangler en behandling af den politiske proces, som førte til de sikkerhedspolitiske dagsordner og deraf følgende 'fodnoter'. I årene 1982-1988 vedtog Folketinget i alt 23 dagsordner vedrørende dansk sikkerhedspolitik. Kun knap halvdelen af disse er overhovedet nævnt i BJ's værk, og endnu færre underkastet en egentlig analyse.

Der er ingen tvivl om, at fodnoterne var et betydeligt irritationsmoment og skadede Danmarks anseelse i Alliancen. Men ligesom Folketingets dagsordner var fodnoterne forskellige. Nogle var rene meningstilkendegivelser, andre havde konkrete sikkerhedspolitiske implikationer. De allierede ledere, specielt i USA og Storbritannien, kunne godt bag lukkede døre se forskel. De vidste godt, at en ensidig nordisk kernevåbenfri zone ikke havde nogen gang på jorden. Til gengæld anfægtede anløbssagen i maj 1988 hele grundlaget for USA's og Storbritanniens - og dermed NATOs - strategi. Men en påpegning af sådanne nuancer ville jo svække den totale afvisning af DIIS-rapporten.

Blandt bogens overraskelser er også den manglende omtale af den såkaldte Dyvigrapport fra 1984, der var et forsøg fra regeringens side (men inspireret af Svend Auken) på at tilvejebringe et grundlag for en ny sikkerhedspolitisk konsensus mellem de 'gamle' partier. Rapporten får blot $1 \frac{1}{2}$ linje! Til gengæld ofres en hel side på det (måske) 'neutralistiske' forsidebillede ikke på rapporten, men på SNU-udgaven med kommentarer og debat. (I billedteksten side [2] 539 betegnet som rapporten). Hverken selve rapportens indhold, der var
Bogens grundholdning er, at alt, hvad den til enhver tid siddende amerikanske regering gjorde, var godt, rigtigt og tjente fredens sag skrevet af en gruppe centrale embedsmænd i Udenrigsministeriet, eller SNU-udgavens 130 sider med gengivelse af de politiske kommentarer til rapporten er omtalt.

Grønlands rolle i dansk sikkerhedspolitik er nævnt flere steder i de to bind, men af uforklarlige grunde ikke i beskrivelsen af 1980'erne. Den til tider intense debat om den amerikanske militære tilstedeværelse i Grønland, specielt de politiske stridigheder om radar- og satellitsporingsstationerne ved Thule og den nye phased array-radars forhold til det amerikanske SDI-projekt og ABM-traktaten er overhovedet ikke behandlet. Kan det skyldes, at i denne sag bøjede Socialdemokratiet sig ikke for pres fra SF og VS, men i marts 1987 stemte for regeringens redegørelse? Heldigvis har vi den store og sobre DUPI-rapport fra 1997 om Grønland under den kolde krig, men den dækker kun tiden op til 1968.

\section{KGB og STASI bag alt}

Socialdemokraterne med Anker Jørgensen og Lasse Budtz i spidsen er med rette de hovedanklagede i BJ's fremstilling. Anker Jørgensen synes at have været motiveret af følelsesmæssig afsky for kernevåbnene og al deres væsen, manglende strategisk forståelse og en god portion stædighed. Han overlod gradvis mere og mere af ansvaret for partiets sikkerhedspolitik til Lasse Budtz på bekostning af andre medlemmer af folketingsgruppen. Hvad der motiverede Budtz står hen i det uvisse.

BJ skriver i indledningen til kapitel 20 om Sovjetunionen og Socialdemokratiets kursskifte, at "der ikke er nogen enkel for- 
klaring på det skred, der . . . i 1980'erne indtraf i Socialdemokraternes sikkerhedspolitik”. Og han opregner kort nogle andre forhold, der dog primært vedrører interne personforhold i Socialdemokratiet. "Men helt se bort fra den sovjetiske faktor ... ville være forkert", skriver BJ. Men det gør han så sandelig heller ikke! For det er værkets helt dominerende tema.

Påvirkningerne er sammenfattet i et skema (side [2] 507). Det er en ren tilståelsessag. Alle påvirkninger af Socialdemokratiets sikkerhedspolitik er (med en enkelt undtagelse) markeret med pile, der har deres udspring i "Kommunistiske stater, herunder internationale afdelinger samt KGB og STASI" og via forskellige 'frontorganisationer', fredsbevægelser, 'opinionen' og det socialdemokratiske samarbejde i Scandilux formede Socialdemokratiets politik. (Undtagelsen er Socialistisk Internationale, der angiveligt også selv havde en vis indflydelse på de kommunistiske stater m.fl.). Ifølge skemaet var der ingen andre indre eller ydre forhold, der påvirkede Socialdemokratiet.

\section{Regeringen og De Radikale}

Modstanden mod NATO's strategi i almindelighed og dobbeltbeslutningen i særdeleshed var udbredt i de socialdemokratiske partier og på venstrefløjen i hele Nordvesteuropa. Det var imidlertid kun i Danmark, at disse strømninger kunne slå igennem i den officielle politik. Den afgørende forskel var den parlamentariske situation, hvor de kritiske holdninger takket være Socialdemokratiet og De Radikale kunne påvirke politikken.

Man savner - her som i flere andre beskrivelser af 1980'ernes sikkerhedspolitik - en nærmere analyse af De Radikales tvetydige rolle. Uden De Radikale havde der ikke været et alternativt sikkerhedspolitisk flertal. De Radikale generede regeringen i sikkerhedspolitikken, men holdt hånden under den i alle øvrige centrale politiske spørgsmål - også når det kom til tillidsafstemninger om regeringens manglende efterlevelse af de sikkerhedspolitiske dagsordener, De Radikale selv havde stemt for. Først da den kolde krig sang på sidste vers og med udsigten til regeringsdeltagelse, sadlede De Radikale om, og dermed døde det alternative sikkerhedspolitiske flertal.

Uanset al den kritik, der med rette kan fremføres mod Socialdemokratiet, specielt mod Anker Jørgensen og Lasse Budtz, så havde det været på sin plads at skrive noget om de borgerlige politikeres og ikke mindst statsminister Poul Schlüters rolle. Hvis de mange udsagn fra danske diplomater, ledende officerer, Forsvarets Efterretningstjeneste og allierede ledere om fodnotepolitikkens skadelige virkninger, som Bent Jensen citerer til overflod, står til troende (hvad de givetvis gør), så burde statsministeren vel have taget den parlamentariske konsekvens heraf og udskrevet valg i stedet for at administrere en politik, han mente var til alvorlig skade for landets sikkerhed.

Som et kuriosum kan det nævnes, at Det Konservative Folkepartis medlem af NATOs Parlamentariske Forsamling på dennes møde i Istanbul i november 1986 af nationale grunde (!) støttede (om end forgæves) Lasse Budtz' kandidatur til forsamlingens formandspost.

Det var i det hele taget karakteristisk, at meget få borgerlige politikere og debattører deltog i debatten med venstrefløjen om kernevåbenpolitik i pressen og ude i det 'forsamlingshusDanmark', som BJ ellers bekender sig til. Der var dog én politiker, der både havde viden og vilje til at debattere. Han var landets udenrigsminister, men er stort set ikke-eksisterende i BJ's fremstilling, når bortses fra nogle nedladende bemærkninger. Det er en af de mest ejendommelige prioriteringer i det 1.500 sider store værk. (At BJ efterfølgende i et indlæg i Weekendavisen erkender, at Uffe Ellemann-Jensen burde have været nærmere omtalt, men undskylder sig med, at bogen primært dre- 
jer sig om Socialdemokratiet, ændrer ikke ved den grundlæggende ubalance i bogens beskrivelse af den kolde krig i Danmark).

Selvom Socialdemokratiet bærer hovedansvaret for 'fodnotepolitikken', så bidrog regeringens valne politik (og uklare linje i afstemningerne om de sikkerhedspolitiske dagsordener) utvivlsomt til at styrke det alternative flertal i Folketinget. For når regeringen ikke tog sine egne erklæringer om fodnoternes skadevirkninger alvorligt, så var det sin sag for de socialdemokrater, der var imod partiets nye linje, at underløbe ledelsen og risikere en alvorlig splittelse i partiet. Man kan vel heller ikke fortænke mange vælgere $\mathrm{i}$ at mene, at det hele nok ikke var så galt, når regeringen valgte at 'leve' med dagsordnerne.

Det var først i 1988, hvor INF-aftalen mellem USA og Sovjetunionen havde løst problemet med mellemdistancevåbnene i Europa og den kolde krig var under begyndende afvikling, at Poul Schlüter tog konsekvensen af anløbssagens potentielt vidtrækkende skadevirkning for det danske NATO-medlemskab og udskrev det valg, der gjorde en ende på 'det alternative sikkerhedspolitiske flertal.'

\section{Kilder}

Bogens første kapitel er en passioneret kritik af PET, Statsministeriet, Udenrigsministeriet og Justitsministeriet for ikke at have givet BJ lov til at citerer fra alle de dokumenter, hvortil han har haft privilegeret adgang. (Kritikken af Morten Bødskov er specielt interessant, da der var konservative politikere på justitsministerposten i hele BJ's Koldkrigscenters levetid!). Uanset, hvad man måtte mene om dette kapitel, så ville det vel have været naturligt at bringe det som indledning til kildeoversigten og ikke som værkets egentlige indledning. Er formålet, at læseren fra starten skal bibringes den opfattelse, at forfatteren ved meget mere, end han har fået lov til at skrive?

Værket indeholder en omfattende littera- turliste og et meget stort noteapparat, der tydeligvis har gjort indtryk på visse anmeldere. Der er også en lang diskussion af relevant litteratur på Gyldendals hjemmeside. For særligt interesserede kan den være nyttig, hvis man kan se bort fra de nedsættende bemærkninger om flere kolleger, hvis tolkninger ikke er i overensstemmelse med BJ's, eller som har et mindre kritisk syn på Sovjetunionen.

Nærværende anmelder har ikke forudsætninger for at vurdere de russisksprogede kilder og har ikke benyttet de offentlige dokumenter, forfatteren har haft adgang til. Men selv med disse begrænsninger er der en del at bemærke vedrørende kilderne og deres anvendelse.

For det første er der en del bøger og artikler i fagtidsskrifter, man savner som fx Erik Beukels Socialdemokratiet og stationeringsproblemet 1952-53 (1974), Hans Henrik Bruuns En premiere, to generalprøver og et kup. Dagsordenafstemningen i Folketinget den 5. september 1985 (2005), hovedparten af de relevante udgivelser fra Det Sikkerheds- og Nedrustningspolitiske Udvalg (SNU), artikler i Dansk Udenrigspolitisk Årbog og tidsskriftet Politica.

Dertil kommer et antal bøger og tidsskriftsartikler, der ganske vist er medtaget på litteraturlisten, men ikke har sat sig synlige spor i teksten. Det gælder fx Nikolaj Petersen og Hans Henrik Holm (red.) Slaget om missilerne. Dobbeltbeslutningen og sikkerheden i Europa (eng. udg. The European Missile Crisis. Nucelar Weapons and Security Policy) begge fra 1983. Ud over en længere indledning rummer den væsentlige bidrag fra udenlandske forskere og danske kommentarer samt de to redaktørers detaljerede analyse af dansk INF-politik.

I en forskningsbaseret fremstilling bør man vel forholde sig argumenterende til andre forskningsbidrag af det pågældende emne. Så selv om BJ (mildt sagt) ikke er nogen beundrer af Poul Villaume, så er Villaumes disputats Allieret med for- 
behold (1995) et så væsentligt værk, at BJ burde være gået i en reel kritisk dialog med det. (Bemærkningerne på Gyldendal-listen er langt fra tilstrækkelige).

Det er ikke alle de mange noter, der har et substantielt indhold. Og flere steder, hvor teksten bringer nye, interessante oplysninger, mangler der kildehenvisninger (og her tænkes ikke på de mange markeringer med røde hamrer og segl, der angiver, hvor myndighederne ikke har givet forfatteren lov til at citere fra klassificeret materiale).

Det er tydeligt, at BJ har været igennem et stort materiale, men han er meget selektiv i sin anvendelse af det. Alt, hvad der kan bekræfte hans 'tese', er med, hvorimod andre kilder og tolkninger behandles tilfældigt for nu at sige det venligt. Der citeres i lange baner fra obskure venstrefløjspublikationer, hvis reelle betydning for dansk politik kan diskuteres, mens flere substantielle behandlinger af emnet er forbigået i tavshed.

Ulve, får og vogtere har været afventet med spænding. Offentliggørelsen førte straks til en debat baseret mere på velkendte ideologiske positioner end på værkets indhold. Men trods de mange sider er vi ikke kommet væsentligt nærmere en forståelse af Danmark under den kolde krig. Nikolaj Petersens Europæisk og Globalt Engagement 1973-2003 (Dansk Udenrigspolitiks Historie bind 6). Gyldendal, 2004 (2. udg. 2006) er stadig den klareste, mest dækkende og bedst skrevne fremstilling af dansk sikkerhedspolitik i 'fodnoteperioden'.

Jensen, Bent: Ulve, får og vogtere.

Den Kolde Krig i Danmark 1945-1991. Bind I og II. Gyldendal 2014, 1505 sider. ISBN 9788702144116 